\title{
Ecological and Economic Prerequisites for the Extraction of Solid Minerals from the Bottom of the Arctic Seas
}

\author{
Alexander Myaskov ${ }^{1, *}$, and Alexander Gonchar ${ }^{1}$ \\ ${ }^{1}$ The National University of Science and Technology MISiS 119049, Leninsky avenue, 4, Moscow
}

\begin{abstract}
The world ocean has huge reserves of minerals that are contained directly in the water, as well as on the surface of its bottom and in its subsoils. The deposits of solid minerals on the surface of the bottom of the World Ocean are considered the most promising for industrial extraction. The deposits of ferromanganese nodules, cobalt-manganese crusts and polymetallic sulphides are considered as an object of extracting more often than others. There are the largest deposits of ferromanganese nodules in the central and southern parts of the Pacific Ocean, in the central part of the Indian Ocean, and in the seas of the Arctic Ocean near Russia. The deposits of ferromanganese nodules are a serious alternative to deposits of manganese ore on land. However, there are many factors influencing the efficiency of the development of ferromanganese deposits, the most significant are: the content of the useful component in the ore, the depth of the bottom and the distance from the seaports. It is also necessary to take into account the possible environmental consequences of underwater mining.
\end{abstract}

\section{Introduction}

The depletion of certain types of minerals in previously explored and now developing deposits, the growth of population in the world, the increase in demands and living standards, the rapid development of science and technology pose a challenge for mankind to increase the extraction of minerals from new sources. A huge role in the solution of this problem will play the resources hidden under the World Ocean surface.

\section{Material and Methods}

Available materials on the study of the World Ocean allow us to conclude that the ocean not only can serve as a supplier of food products and hydrocarbon raw materials, but also inexhaustible in the foreseeable future a source of solid mineral raw materials. The world ocean is a giant "pantry" with three "regiments" [1-6]:

\footnotetext{
*Corresponding author: Myaskov@misis.ru
} 
- sea water with 95 chemical elements dissolved in it, which in total amount to 50,000,000 billion tons (sodium, potassium, lithium, rubidium, iron, manganese, molybdenum, uranium, zinc, chromium, vanadium, copper, gold, etc.);

- solid minerals from the ocean floor: deep-sea polymetallic sulphides (SPS), ferromanganese concretions, cobalt-manganese crusts, placer tin, gold, titanium, zirconium, rare earth elements, metalliferous silts, amber, etc.;

- mineral resources (oil, gas, ferrous and non-ferrous metals, etc.).

The most promising from industrial development point of view are the mineral resources of the seabed - the shelf zone, the continental slope and the ocean floor, in connection with:

- the absence of minerals contained in offshore fields in the range of minerals extracted;

- lower cost of production compared to existing deposits on land;

- higher content of useful components in the ore in comparison with existing continental deposits;

- less environmental damage, compared with the development of existing deposits on land;

- depletion of developed polymetallic ores deposits on land.

\section{Results and Discussion}

Total reserves of minerals in the ocean floor are difficult to estimate, but the development of explored deposits covers the need for solid minerals by $50-250 \%$ for various types of raw materials in upcoming decades.

The major attention of technologically advanced countries of the world is attracted to the iron-manganese formations of the seabed, deep-sea polymetallic sulphides and metalliferous silt, which contain the multicomponent composition (up to 50 elements), as well as the high content of useful components.

Iron-manganese concretions of the bottom of the World Ocean are concentrated as much as possible in several ore fields with uneven distribution. More than $50 \%$ of the bottom area is covered by the nodules in some sections. Most concretions are concentrated in the center of the Pacific Ocean between the latitudinal faults of Clarion and Clipperton along the equator for thousands of kilometers. In addition to the Clarion-Clipperton areas with high concentrations of ferromanganese formations are also found in the central Indian Ocean, in the seas of the Arctic Ocean, in the southern and southeastern parts of the Pacific Ocean [7-13].

To understand the scope of possible alternative to terrain deposits of polymetallic ores (in this case manganese ores), it is best to turn to the comparative table of geological and economic indicators of the Clarion-Clipperton field, the Kara Sea, the most studied sea of the Arctic Ocean, and to Usinskoe manganese deposit . 1).

Table 1. Geological and economic indicators of manganese deposits

\begin{tabular}{|l|c|c|c|}
\hline & $\begin{array}{c}\text { Clarion-Clipperton } \\
\text { field }\end{array}$ & Kara Sea & Usinskoe deposit \\
\hline $\begin{array}{l}\text { The content of the } \\
\text { useful component in } \\
\text { the ore, } \%\end{array}$ & $20.8-21.8$ & $6.8-7.9$ & $16.7-19.6$ \\
\hline $\begin{array}{l}\text { Ore reserves, million } \\
\text { tons }\end{array}$ & 300 & 34.9 & 98.5 \\
\hline Value, \$ billion & 127.8 & 5.2 & 35.7 \\
\hline $\begin{array}{l}\text { The self-cost of min- } \\
\text { ing } 1 \text { ton of ore, } \$\end{array}$ & 322 & 203 & 672 \\
\hline
\end{tabular}


In addition to the concentration of minerals in the ore, a number of other factors, especially geographic ones such as depth of development and remoteness from land, have a significant impact on the economic efficiency of solid minerals mining from the bottom of the World Ocean.

Depending on the depth of the seabed, the methods of deposits development vary considerably, and even it is possible to modify existing technologies from related industries, for example, using dredges, then at considerable depths there is a need to create and maintain new mechanisms and machines, requiring significant costs (Figure 1).

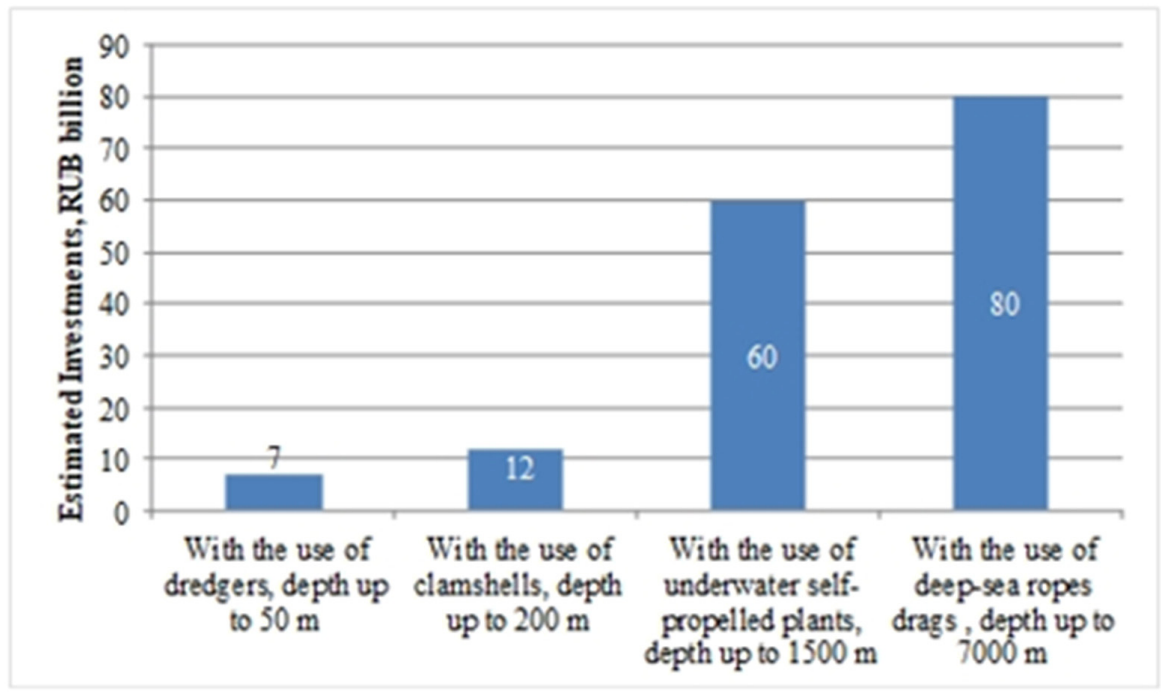

Fig. 1. Estimated value of capital expenditures for the projects designing for development of ferromanganese nodules deposits of the ocean floor

The next important geographical factor affecting the expediency of offshore mineral deposits development is their remoteness from seaports. First of all it affects transport costs, in addition, it leads to increasing the losses of the mineral (Figure 2).

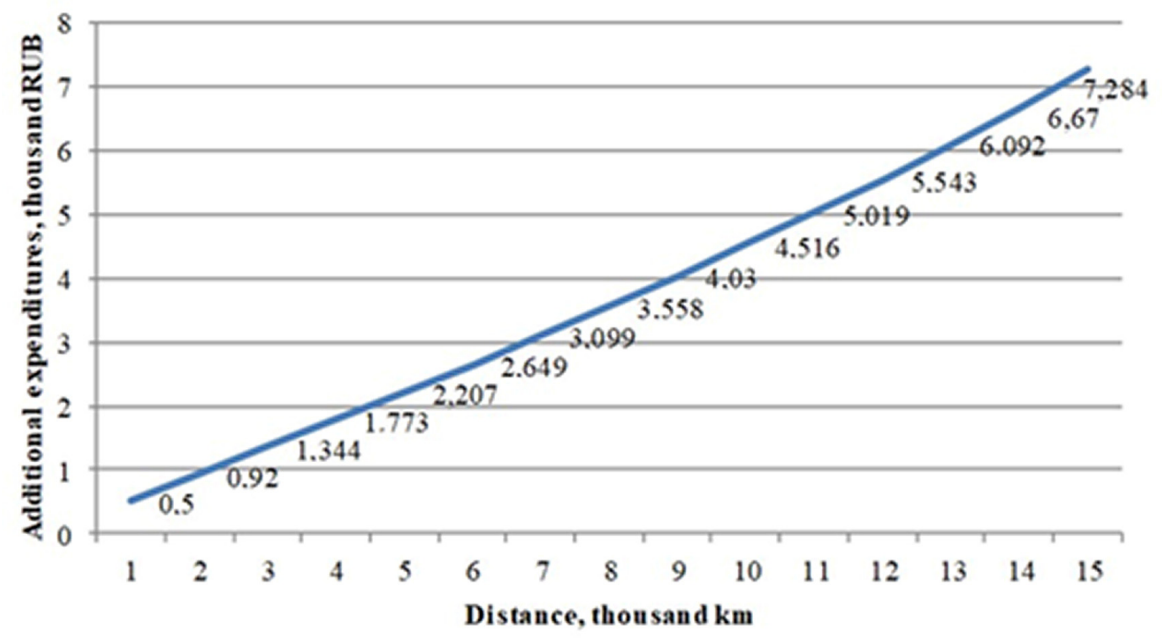

Fig. 2. Additional transportation costs per one ton of minerals, depending on the remoteness of the field from seaports 
Due to the small depth of the Arctic seas in the water area of Russian Federation and the short distance to seaports, it can be concluded that the deposits of ferromanganese nodules of the Arctic seas, including the Kara Sea, have some competitive advantages for Russia before other deposits manganese.

In addition to the economic side of the issue, it is also necessary to take into account the consequences of sea deposits development on the surrounding natural environment. In the last century the International Oceanographic Commission of UNESCO adopted the rule that sea pollution is the introduction of substances or energy into the marine environment that leads to harmful or irreversible effects that damage the living resources and health of people, interfere with the activities of marine organisms, deteriorate the quality of the marine environment and disrupt the elements of the "ocean-atmosphere" system [14-18].

The main negative impacts for the marine environment during the seabed field's development will be:

- increase in the concentration of suspended material, leading to the loss of a significant amount of flora and fauna;

- violation of the oxygen regime in the region;

- transformation of the relief in the place of development;

- accumulation of chemicals.

Due to a simpler configuration of the surface of the seabed of the Arctic seas, solid minerals extraction in their water areas is safer because the relief transformations, as well as changes in the concentration of the material weighed in sea water, are minimized. In addition, due to the small depth, there is no serious disturbance of the oxygen regime resulting from the rise of deep waters, which are harmful to the inhabitants of the upper layers of the water column. This allows us to conclude that the development of solid mineral deposits in the Arctic seas has its positive aspects in relation to the development of deposits located in three other oceans.

\section{Conclusion}

At present, the Russian Federation does not extract manganese ore, so needed by metallurgy. Raw materials for them are imported from China, Kazakhstan and Ukraine. The beginning of national manganese ores deposits development would allow reducing dependence on foreign partners and also lowering expenses for manganese raw materials for domestic enterprises. Given the low production costs, relatively low environmental risks, the deposits of ferromanganese nodules of the Arctic seas should be regarded as a strategic source of manganese. So the further steps towards the beginning of industrial development of these deposits must be taken.

\section{References}

1. E. Baker, Y. Beaudoin, Deep Sea Minerals: Seafloor Massive Sulphides, a Physical, Biological, Environmental, and Technical Review (London: SPC, 2013)

2. M.L.C.M. Henckens, P.P.J. Driessen, E. Worrell, Resour. Conserv. Recycl. 93, 1-8. (2014)

3. K.V. Ragnarsdottir, Nat. Geosci. Comment. 1, 720-721 (2008)

4. W.J. Rankin, Minerals, metals and sustainability, Meeting Future Material Needs (New York, CRC Press, 2011) 
5. R. Spickermann, Rare earth content of manganese nodules in the Lockheed Martin Clarion-Clipperton Zone exploration areas. Offshore Technology Conference Number (OTC-23084-MS, 2012)

6. A. Thurnherr, C. Young, Front. Mar. Sci. 2 (2015)

7. R.E. Boschen, A.A. Rowden, M.R. Clark, J.P.A. Gardner, Ocean. Coast Man. 84, 54-67 (2013)

8. M.D. Hannington, J. Jamieson, T. Monecke, S. Petersen, Soc. Econ. Geol. Spec. Publ. $15,317-338(2010)$

9. M. Hannington, J. Jamieson, T. Monecke, S. Petersen, S. Beaulieu, Geol. 39, 1155-1158 (2011)

10. J.R. Hein, T.A. Conrad, R.E. Dunham, Mar. Georesour. Geotechnol. 27, 160-176 (2009)

11. J.R. Hein, T.A. Conrad, H. Staudigel, Oceanography, 23, 184-189 (2010)

12. J.R. Hein, Prospects for rare earth elements from marine minerals. Briefing Paper 02/12, International Seabed Authority (2012)

13. A.A. Rowden, J.F. Dower, T.A. Schlacher, M. Consalvey, M.R. Clark, Mar. Ecol. 31, 226-241. 2010

14. K. Bohmann, A. Evans, M.T.P. Gilbert, G.R. Carvalho, S. Creer, M. Knapp, D.W. de Bruyn, Trends Ecol. Evol. 29, 358-367 (2014)

15. P.C. Collins, R. Kennedy, C.L. Van Dover, Mar. Ecol. Prog. Ser. 452, 89-107 (2012)

16. ISA, International Seabed Authority. Biodiversity, species ranges, and gene flow in the abyssal Pacific nodule province: predicting and managing the impacts of deep seabed mining (Kingston, Jamaica: ISA Technical Study, 2008)

17. R. Martone, L. Hannah, L. Greig, B. Boutillier, S. Patton, 2015. DFO Can. Sci. Advis. Sec. Res. Doc. 072:66 (2014)

18. M. Prekopová, J. Janočko, Geol. Carp., 60:6, 485-494 (2009) 
